\title{
PERANCANGAN DAN PENERAPAN SISTEM INFORMASI KENOTARIATAN MENGGUNAKAN BAHASA PEMROGRAMAN PHP
}

\author{
Muhammad Ichsan Adhiim ${ }^{1)}$, Adian Fatchur Rochim ${ }^{2)}$, Eko Didik Widianto ${ }^{2)}$ \\ Program Studi Sistem Komputer, Fakultas Teknik, Universitas Diponegoro, \\ Jln. Prof. Sudharto, Tembalang, Semarang, Indonesia \\ email : ichanadhiim@gmail.com
}

\begin{abstract}
Notary is a judicial officer who is authorized to make an authentic deed and agreements of individuals, institutions, or land properties. In the daily work, Notary records customer data and work data. However, the result of recording data manually makes Notary overwhelmed in data processing, causing task completion time becomes longer.

The Notary Information System is designed using Waterfall methodology using PHP programming language, Code Igniter framework, and MySQL database. Analysis of system requirements is is conducted by interviewing the Notary, so the design is appropriate and well targeted.

This research produces an information system that is capable of recording type of work data, customer data, land, property data, employment data, income and outcome data, and data revenue recapitulation in the form of text and graphics data. This information system design also has an additional functions that notifies the clients about the completed work via E-mail and SMS. This information system design was tested using the black box method, and the results of these tests indicate that all functions in the system have been running well.
\end{abstract}

Keyword : Notary, Information System, Waterfall, Black-box

\section{PENDAHULUAN}

Notaris adalah pejabat umum yang satu-satunya berwenang untuk membuat akta otentik mengenai semua perbuatan, perjanjian dan penetapan yang diharuskan oleh suatu peraturan umum atau oleh yang berkepentingan dikehendaki untuk dinyatakan dalam suatu akta otentik, menjamin kepastian tanggalnya, menyimpan aktanya dan memberikan grosse, salinan dan kutipannya, semuanya sepanjang pembuatan akta itu oleh suatu peraturan tidak dikecualikan. Sedangkan Pejabat Pembuat Akta Tanah (PPAT) adalah pejabat umum yang diberi kewenangan untuk membuat akta-akta otentik mengenai perbuatan hukum tertentu mengenai hak atas tanah atau hak milik atas satuan rumah susun. Notaris dan PPAT adalah dua profesi yang berbeda dengan kewenangan yang berbeda pula, namun dimungkinkan untuk seorang notaris merangkap jabatan sebagai PPAT. Hal ini diatur dalam Pasal 17 huruf g UU No. 30 Tahun 2004 tentang Jabatan Notaris ${ }^{[4]}$

Dalam keseharian pekerjaan Notaris dan PPAT, dilakukan pencatatan data klien dan data pekerjaan yang masuk untuk kemudian dilakukan proses sesuai dengan jenis pekerjaan yang diajukan oleh klien. Namun hasil pencatatan data secara manual dan kurang terperinci membuat Notaris kewalahan dalam memantau perkembangan pekerjaan, pencarian data pekerjaan, hingga pemantauan alur keuangan. Hal ini dapat menyebabkan waktu untuk menyelesaikan pekerjaan menjadi lebih lama dan juga adanya celah bagi karyawan untuk memanipulasi biaya yang harus dikeluarkan Notaris untuk sebuah pekerjaan.

Berdasarkan permasalahan diatas, dilakukan penelitian yang bertujuan untuk merancang sebuah sistem informasi kenotariatan yang dapat membantu mempermudah Notaris dan karyawan dalam pencatatan, pemantauan, pencarian data pekerjaan dalam proses kerja sehari-hari, serta pemberitaan kepada klien jika proses pekerjaan telah selesai melalui SMS dan email secara otomatis.

Untuk menghindari permasalahan yang meluas, maka dalam penelitian Tugas Akhir ini ditetapkan beberapa batasan masalah yaitu Sistem Informasi Kenotariatan dibangun menggunakan bahasa pemrograman PHP dengan framework Codeigniter versi 2.2, kemudian sistem informasi ini dapat digunakan untuk menambahkan dan mengelola data informasi klien, menambahkan dan mengelola data informasi tanah, menambahkan dan mengelola data pekerjaan, melihat dan mengubah status perkembangan pekerjaan, menambahkan dan mengelola jenis pekerjaan yang dapat dilakukan oleh Notaris dan PPAT, langkah-langkah proses pekerjaan, dan syarat pekerjaan untuk tiap jenis pekerjaan, melihat rekap data dan pendapatan, serta mengirimkan SMS dan email secara otomatis. Fitur SMS Gateway dan Phpmailer dalam sistem ini hanya untuk pemberitaan kepada klien bahwa proses pekerjaan telah selesai.

\section{Metode Penelitian}


Sistem informasi yang dikembangkan menggunakan metodologi Waterfall. Metodologi ini terdiri atas beberapa tahap yaitu analisis kebutuhan, perancangan, implementasi, pengujian, dan pemeliharaan.

Tahap analisis kebutuhan merupakan tahap pengumpulan kebutuhan pengguna dan kemudian di transformasikan kedalam bentuk deskripsi yang jelas. Tahap ini memuat alur kerja dari instansi beserta kendala yang dialami oleh instansi tersebut dan juga keinginan pengguna terhadap kendala yang ada. Pada penelitian ini, data analisis kebutuhan didapatkan dari hasil wawancara dengan salah satu Notaris dikota Semarang yaitu kantor Notaris dan PPAT Sriyati Sartopo Putri, S.H.

Tahap perancangan perangkat lunak mencakup atribut-atribut pada perangkat lunak. Tahap ini menerjemahkan kebutuhan ke dalam sebuah model perangkat lunak dan bentuk rancangan analisis sistem yang berisi Entity Relationship Diagram (ERD), dan UML.

Tahap implementasi merupakan tahap penerjemahan konsep atau rancangan kedalam sebuah bahasa pemrograman. Rancangan ERD diterjemahkan kedalam tabel-tabel basis data MySQL, sedangkan rancangan UML diterjemahkan kedalam bahasa pemrograman PHP menggunakan framework Codeigniter.

Tahap pengujian program merupakan tahap pengujian dari hasil implementasi program. Pengujian menggunakan metode black-box dimana pengujian dilakukan pada fungsi-fungsi yang ada pada sistem. Keberhasilan pengujian diukur dari terpenuhinya kebutuhan yang telah dianalisis sebelumnya.

Tahap pemeliharaan adalah tahap dimana perangkat lunak yang dibangun telah digunakan oleh pengguna dan dilakukan pemeliharaan secara berkala sesuai dengan kebutuhan pengguna dan kesepakatan yang telah dibentuk oleh pembuat sistem dengan pengguna.

\section{PERANCANGAN SISTEM}

Analisa kebutuhan merupakan tahapan awal yang menentukan seperti apa sistem yang akan dihasilkan dan apakah sistem yang dibangun sesuai dengan kebutuhan pengguna. Sistem informasi yang dibangun harus dapat melakukan fungsi mempermudah pegawai dalam pengelolaan dan pencarian data klien, mempermudah pegawai dalam pengelolaan dan pencarian data pekerjaan yang sedang berlangsung, mempermudah Notaris dalam pemantauan pekerjaan, melihat rekapitulasi data pekerjaan, pengelolaan biaya pengeluaran pekerjaan, serta melihat rekapitulasi pendapatan, dan mempermudah instansi dalam memberikan pemberitaan kepada klien bilamana proses pekerjaan telah selesai dikerjakan. Pemberitaan dapat melalui SMS maupun email.

Kebutuhan non-fungsional merupakan kebutuhan yang tidak berkaitan langsung dengan fitur-fitur yang ada. Namun kebutuhan ini memberikan batasan terhadap kebutuhan fungsional. Kebutuhan non-fungsional dari sistem yang akan dibangun meliputi kebutuhan operasional dan kebutuhan keamanan. Kebutuhan operasional yaitu sistem memiliki fitur pesan kesalahan bilamana pengguna melakukan kesalahan pada saat menggunakan sistem. Sedangkan kebutuhan keamanan yaitu sistem memiliki fitur login untuk mengijinkan pengguna menggunakan aplikasi. Sistem memberikan rule yang berbeda pada tiap hak akses pengguna guna memberikan batasan terhadap tiap hak aksesnya.

Sistem informasi yang akan dibangun juga memerlukan kebutuhan yang mendukung implementasi sistem yang disebut kebutuhan aplikasi. Kebutuhan aplikasi terdiri atas kebutuhan operasional, kebutuhan antarmuka, dan kebutuhan keamanan.

Kebutuhan operasional meliputi kebutuhan minimum yang diperlukan untuk menjalankan sistem informasi yang akan dibangun. Sistem operasi yang dapat digunakan antara lain Windows, Mac OS, dan Linux. Kebutuhan versi bahasa pemrograman PHP minimum yang dapat digunakan yaitu versi 5.1.6 (versi PHP minimum yang mendukung framework Code Igniter). Web browser yang dapat digunakan antara lain Internet Explorer versi 7+, Mozilla Firefox, Google Chrome, Safari, dan Opera (browser yang mendukung bootstrap). Kebutuhan basis data MySQL minimum yang dapat digunakan yaitu versi 4.1 (versi MySQL minimum yang mendukung framework Code Igniter).

Kebutuhan antarmuka merupakan tampilan yang disajikan dari aplikasi yang dibuat. Antarmuka menentukan bagaimana pengguna dapat memahami dan menggunakan sebuah aplikasi. Antarmuka yang baik adalah antarmuka yang mampu memberikan tujuan dengan baik kepada pengguna, dan pewarnaan serta tatanan layout membuat pengguna nyaman dalam menggunakan aplikasi.

Kebutuhan keamanan data merupakan salah satu unsur penting dalam pembuatan sebuah sistem terutama dalam menjaga data dari pengguna yang tidak berwenang untuk mengolah data tersebut. Dalam sistem ini, pengamanan dilakukan dengan mengenkripsi password pengguna dengan menggunakan metode MD5.

Pemodelan sistem merupakan tahap penggambaran desain sistem yang berfokus pada fungsi-fungsi dan 
atribut aplikasi. Sistem didesain menggunakan pemodelan UML (Unified Modelling Language). Didalam pemodelan UML terdapat Use Case Diagram, Class Diagram, Sequence Diagram, dan Deployment Diagram.

Use Case Diagram merupakan pemodelan untuk kelakuan sistem yang akan dibuat. Use Case Diagram menggambarkan fungsionalitas yang diharapkan dari sebuah sistem. Use Case Diagram dari sistem yang akan dibangun dapat dilihat pada lampiran Gambar 1.

Class Diagram menggambarkan struktur dan deskripsi class, package, dan objek beserta hubungan satu sama lain. Class Diagram dari sistem yang akan dibangun ditunjukkan pada lampiran Gambar 2.

Sequence Diagram menggambarkan interaksi antar objek didalam dan disekitar sistem yang berupa pesan yang digambarkan terhadap waktu.

Sequence Diagram Login berisikan proses dimana pengguna mengisi form data agar dapat masuk kedalam sistem. Sequence Diagram Login ditunjukkan pada lampiran Gambar 3.

Sequence Diagram Mengelola Jenis Pekerjaan, Detail Pekerjaan, Syarat Pekerjaan berisikan proses dimana staf khusus melakukan manajemen daftar pekerjaan. Sequence Diagram Mengelola Jenis Pekerjaan, Detail Pekerjaan, Syarat Pekerjaan ditunjukkan pada lampiran Gambar 4.

Sequence Diagram Mencatat Identitas Klien dan Informasi Berkas berisikan proses staf melakukan pencatatan identitas klien dan juga informasi berkas. Sequence Diagram Mencatat Identitas Klien dan Informasi Berkas ditunjukkan pada lampiran Gambar 5.

Sequence Diagram Input Pekerjaan Baru berisikan proses staf melakukan penambahan pekerjaan dengan mengisikan form yang telah tersedia. Sequence Diagram Input Pekerjaan Baru ditunjukkan pada lampiran Gambar 6.

Sequence Diagram Mengelola Pekerjaan berisikan proses Staf mengelola detail, syarat, serta biaya titip dari pekerjaan. Sequence Diagram Mengelola Pekerjaan ditunjukkan pada lampiran Gambar 7.

Sequence Diagram Informasi Pekerjaan Selesai berisikan proses staf memberikan pemberitaan kepada klien melalui email atau SMS Gateway. Sequence Diagram Informasi Pekerjaan Selesai ditunjukkan pada lampiran Gambar 8.

Sequence Diagram Melihat Rekap Data Pekerjaan berisikan proses pengguna melihat pekerjaan yang telah selesai dikerjakan. Sequence Diagram Melihat Rekap Data Pekerjaan ditunjukkan pada lampiran Gambar 9.

Sequence Diagram Mengelola Pekerjaan Baru berisikan proses Notaris menyetujui permohonan pekerjaan baru yang telah didaftarkan oleh Staf. Sequence
Diagram Mengelola Pekerjaan Baru ditunjukkan pada lampiran Gambar 10.

Sequence Diagram Mengelola Pekerjaan Selesai berisikan proses Notaris mengesahkan hasil pekerjaan Staf. Sequence Diagram Mengelola Pekerjaan Selesai ditunjukkan pada lampiran Gambar 11.

Sequence Diagram Mengelola Pengeluaran Kerja berisikan proses Notaris membayarkan biaya pekerjaan. Sequence Diagram Mengelola Pengeluaran Kerja ditunjukkan pada lampiran Gambar 12.

Sequence Diagram Mengelola Rekap Pendapatan berisikan Notaris melihat rekapitulasi pendapatan. Sequence Diagram Melihat Rekap Pendapatan ditunjukkan pada lampiran Gambar 13.

Sequence Diagram Mengelola Pengguna berisikan proses Admin mengelola pengguna dari sistem. Sequence Diagram Mengelola Pengguna ditunjukkan pada lampiran Gambar 14.

Deployment Diagram menggambarkan detail bagaimana komponen di-deploy dalam infrastruktur sistem dan dimana letak komponen. Deployment Diagram ditunjukkan pada lampiran Gambar 15.

Entity Relationship Diagram (ERD) merupakan bentuk pemodelan perangkat lunak yang berupa konseptual yang merepresentasikan data tertentu. ERD ditunjukkan pada lampiran Gambar 16.

\section{IMPLEMENTASI DAN PENGUJIAN}

Implementasi dan pengujian dilakukan setelah sistem dirancang dengan baik. Implementasi dibagi menjadi dua yaitu implementasi program dan implementasi tabel basis data. Implementasi program dilakukan dengan cara menuliskan fungsi-fungsi dan tampilan kedalam baris kode pemrograman. Sedangkan implementasi tabel dilakukan dengan cara mengimplementasikan rancangan tabel kedalam basis data sesuai dengan analisis sebelumnya. Tampilan hasil implementasi program ditunjukkan pada lampiran Gambar 17 dan lampiran Gambar 18

Proses pengujian menggunakan metode black-box dibagi menurut fungsi dari masing-masing menu sesuai dengan kegunaannya. Bentuk pengujian berupa cara pengguna menggunakan aplikasi. Hasil pengujian sistem secara keseluruhan ditunjukkan pada Tabel 1.

Tabel 1 Hasil Pengujian Sistem

\begin{tabular}{|l|c|}
\hline \multicolumn{1}{|c|}{ Nama Pengujian } & $\begin{array}{c}\text { Hasil } \\
\text { Pengujian }\end{array}$ \\
\hline Pengujian menu login & Berhasil \\
\hline Pengujian menu beranda & Berhasil \\
\hline Pengujian menu daftar pekerjaan & Berhasil \\
\hline Pengujian menu klien & Berhasil \\
\hline Pengujian menu data tanah & Berhasil \\
\hline
\end{tabular}




\begin{tabular}{|l|c|}
\hline Pengujian menu pekerjaan baru & Berhasil \\
\hline Pengujian menu penerimaan tertunda & Berhasil \\
\hline $\begin{array}{l}\text { Pengujian menu berkas pekerjaan dalam } \\
\text { proses }\end{array}$ & Berhasil \\
\hline Pengujian menu berkas pekerjaan selesai & Berhasil \\
\hline Pengujian menu pengeluaran kerja & Berhasil \\
\hline Pengujian menu pengeluaran tambahan & Berhasil \\
\hline Pengujian menu rekap pekerjaan & Berhasil \\
\hline Pengujian menu akun setting & Berhasil \\
\hline Pengujian menu kelola user & Berhasil \\
\hline
\end{tabular}

Bentuk pengujian yang dilakukan terhadap sistem secara detail ditunjukkan pada lampiran Tabel 1 hingga Tabel 14.

Hasil pengujian menggunakan metode black-box, menunjukkan bahwa sistem telah berjalan sesuai dengan spesifikasi kebutuhan dan perancangan aplikasi. Secara fungsional, sistem telah dapat menghasilkan keluaran yang diharapkan.

Sistem Informasi Kenotariatan ini memiliki kelebihan dan kekurangan. Kelebihan Sistem Informasi ini adalah sistem memiliki tampilan yang mudah dipahami dan digunakan, sistem dapat memudahkan karyawan notaris dalam memberikan laporan terhadap notaris perihal proses pekerjaan, sistem dapat memudahkan notaris dalam memantau pekerjaan dan mengelola keluar masuk keuangan, dan sistem mampu memberikan kemudahan dalam memberikan informasi bahwa pekerjaan telah selesai kepada klien melalui email dan SMS Gateway.

Sistem informasi ini juga memiliki kekurangan diantaranya adalah sistem masih bersifat lokal sehingga tidak dapat diakses apabila pengguna tidak berada dalam jaringan lokal. Selain itu, pengguna juga dituntut untuk paham tentang penggunaan komputer agar bisa menggunakan sistem secara optimal.

\section{PENUTUP}

Berdasarkan hasil analisis dan pengujian Sistem Informasi Kenotariatan, dapat disimpulkan beberapa hal yaitu Sistem Informasi Kenotariatan dapat mengolah data pekerjaan Notaris dan PPAT dengan resiko kehilangan data atau kerusakan lebih kecil dibanding metode konvensional. Sistem Informasi Kenotariatan dapat dengan mudah digunakan oleh pengguna karena sistem dirancang untuk bekerja sesuai dengan bisnis proses yang ada sehingga mempermudah proses adaptasi pengguna. Sistem Informasi Kenotariatan dapat menampilkan rekap pendapatan dalam bentuk grafik sehingga memudahkan Notaris untuk mengetahui informasi pendapatan. Sistem Informasi Kenotariatan belum mampu menampilkan pemberitahuan secara real time. Untuk mendapatkan pemberitahuan terbaru, sistem perlu dilakukan refresh. Sistem Informasi Kenotariatan mampu menjaga keutuhan data yang memiliki integrasi sehingga data yang dihapus tidak mempengaruhi keabsahan data lainnya.

Saran untuk pengembangan perangkat lunak di masa yang akan datang, antara lain perlu dilakukan penelitian lebih lanjut untuk mengembangkan Sistem Informasi Kenotariatan agar lebih informatif seperti menambahkan timeline aktivitas pekerjaan. Perlu dilakukan penelitian lebih lanjut untuk mengembangkan Sistem Informasi Kenotariatan agar dapat di akses pada jarak jauh atau membuat sistem menjadi online. Perlu dilakukan penelitian lebih lanjut untuk mengembangkan Sistem Informasi Kenotariatan agar dapat menjadi sistem komunikasi dua arah antara klien dan pihak Notaris baik itu melalui fitur SMS, email, atau fitur lainnya. Perlu dilakukan penelitian lebih lanjut untuk mengembangkan Sistem Informasi Kenotariatan dalam menjamin keamanan data username dan password pengguna sehingga meminimalisir celah penyalah gunaan kewenangan pengguna. Perlu dilakukan backup data secara berkala untuk menanggulangi kehilangan maupun kerusakan data. 